\title{
Administration of Mucuna Beans (Mucuna Pruriences (L.) DC. Var. Utilis) Improves Cognition and Neuropathology of 3×Tg-AD Mice
}

Fumiko Konishi ( $\square$ fkonishi@eiyo.ac.jp )

Kagawa Nutrition University

Tadasu Furusho

Tokyo University of Agriculture

Yoshiyuki Soeda

Gakushuin University

Jun Yamauchi

Tokyo University of Agriculture

Shoko Kobayashi

The University of Tokyo

Masatoshi Ito

Tokai University

Takuma Araki

Tokai University

Sarasa Kogore

Tokyo University of Agriculture

Akihiko Takashima

Gakushuin University

Susumu Takekoshi

Tokai University School of Medicine

\section{Research Article}

Keywords: Alzheimer's disease, amyloid-beta peptides, tau protein, Mucuna beans

Posted Date: September 20th, 2021

DOI: https://doi.org/10.21203/rs.3.rs-885340/v1

License: (1) (1) This work is licensed under a Creative Commons Attribution 4.0 International License.

Read Full License 


\section{Abstract}

Alzheimer's disease $(A D)$ is a neurodegenerative disorder characterized by the accumulation of extracellular amyloid-beta peptides $(A B)$ resulting in senile plaques and intracellular hyperphosphorylated tau protein resulting in neurofibrillary tangles (NFTs). Mucuna beans (Mucuna pruriences (L.) DC. var. utilis) are unique plants containing 3\%-9\% L-3,4-dihydroxyphenylalanine (L-DOPA). Here we investigated the effect of the administration of Mucuna beans on AD prevention by feeding triple-transgenic mice ( $3 \times \mathrm{Tg}-\mathrm{AD}$ mice) with a diet containing Mucuna beans for 13 months. The levels of $A \beta$ oligomers and detergent-insoluble phosphorylated tau decreased in the brain of mice fed with Mucuna beans (Mucuna group) compared to those of the Control group. $A \beta$ accumulation and phosphorylated tau accumulation in the brain in the Mucuna group were also reduced. In addition, administration of Mucuna beans improved cognitive function. These results suggest that administration of Mucuna beans may have a preventive effect on AD development in 3×Tg-AD mice.

\section{Introduction}

Alzheimer's disease (AD) is the most common type of dementia accompanied by memory impairment and neuronal loss. The pathological features of $A D$ are the accumulation of aggregated amyloid-beta peptides $(A \beta)$ and neurofibrillary tangles (NFTs) composed of hyper-phosphorylated tau protein ${ }^{1}$.

$A \beta$ molecules have self-aggregation properties and are prone to forming soluble oligomers with a $\beta$-sheet structure, protofibrils, and then insoluble fibrils as the final stage ${ }^{23}$. A growing body of studies has suggested that soluble $A \beta$ oligomers are neurotoxic and potently inhibit long-term potentiation 456 . Shankar et al. found that $A \beta$ oligomers disrupted synaptic function as well as memory function ${ }^{4}$. They also indicated that $A \beta$ dimers are the smallest neurotoxic molecules ${ }^{4}$.

Tau proteins are primarily present in the distal portion of axons and control microtubule stabilization, regulate axonal transport, and maintain neuronal function ${ }^{7}$. When tau is abnormally phosphorylated in its microtubule-binding domain, it loses the ability to bind and stabilize microtubule assembly, leading to the dysfunction of axonal transport, synaptic loss, and neuronal death ${ }^{7}$. Dislodged tau from microtubules self-assembles into tau oligomers (Sarkosyl-soluble), granular tau oligomers (Sarkosylinsoluble), and fibrils that form NFTs ${ }^{8}$. Granular tau oligomers are a major neurotoxic protein and are associated with neuronal loss ${ }^{910}$. Taken together, the formation of neurotoxic oligomers seems to be a common characteristic for $A \beta$ and tau. Therefore, it might be an attractive strategy for $A D$ prevention to search for compounds that inhibit the aggregation of both $A \beta$ and tau.

Hamaguchi et al. found that feeding AD-model mice with a diet containing rosmarinic acid (RA) reduced $A \beta$ oligomer formation ${ }^{11}$. Regarding the mechanism of this reduction, Hase et al. demonstrated that feeding with a RA-containing diet increased the levels of catecholamines including L-3,4dihydroxyphenylalanine (L-DOPA), norepinephrine (NE), dopamine (DA), and 3,4-dihydroxyphenylacetic acid (DOPAC) in the mouse brain, through downregulation of the expression of DA-degrading enzymes ${ }^{12}$. 
Moreover, these catecholamines inhibited $A \beta$ aggregation in vitro. Therefore, an increase in catecholamine levels in the brain might be beneficial for $A D$ pathogenesis.

Compounds with a catechol skeleton including L-DOPA, DA, and NE also have an inhibitory effect against the tau aggregation in a dose-dependent manner in vitro ${ }^{13}$. The catechol moiety plays an inhibitory role in tau aggregation by interacting with Cys residues in tau ${ }^{13}$. Therefore, compounds with a catechol skeleton structure, including catecholamines are expected to be an agent for preventing AD by hindering the aggregation of both $A \beta$ and tau.

The Mucuna bean (Mucuna pruriences (L.) DC. var. utilis) plant is a heavy cropper, and these beans are eaten mainly in Asia and Africa ${ }^{14}$. Mucuna beans contain 3-9\% L-DOPA, while other plants rarely contain such high amount of the molecule ${ }^{14} 15$. L-DOPA is potentially toxic when ingested in large doses. Thus, intake of Mucuna beans in large amounts at once often causes nausea and vomiting in humans owing to their high L-DOPA content ${ }^{16}$. However, if Mucuna beans are processed properly to control the amount of L-DOPA, the intake of Mucuna beans might be effective for the prevention of AD through inhibition of $A \beta$ and tau aggregation.

To investigate this possibility, we examined the biological effect of Mucuna bean administration on AD prevention by feeding triple-transgenic mice $(3 \times \mathrm{Tg}-\mathrm{AD}$ mice) that express three mutant human transgenes: amyloid precursor protein $\left(\mathrm{APP}_{\text {swe }}\right)$, presenilin-1 $\left(\mathrm{PS}_{\mathrm{M} 146 \mathrm{~V}}\right)$, and four-repeat tau $\left(\operatorname{tau}_{\mathrm{P} 301 \mathrm{~L}}\right)$. These mice progressively develop $A D$ pathology, including $A \beta$ accumulation and phosphorylated tau accumulation ${ }^{17}$. $3 \times \mathrm{Tg}$-AD mice also develop age-dependent cognitive impairment before the accumulation of $A \beta$ and phosphorylated tau with aging ${ }^{18}$. Mucuna beans were fed to these mice, and the levels of $A \beta$ oligomers and phosphorylated tau in the brain were compared to mice fed with a standard diet. Behavioral changes and accumulation of $A \beta$ and phosphorylated tau in the brain were also assessed.

\section{Materials And Methods}

The present study is reported in accordance with ARRIVE guidelines.

\section{Animals and treatment}

Four-week-old female $3 \times$ Tg-AD mice harboring three mutant genes (APPswe, PS1 ${ }_{\text {M146V, }}$, and tau P301L) ${ }^{17}$ were purchased from the Jackson Laboratory, Bar Harbor, ME, USA. The mice were housed individually at a temperature of $24^{\circ} \mathrm{C} \pm 2^{\circ} \mathrm{C}$ at $40 \%-50 \%$ relative humidity and a $12 \mathrm{~h}$ light-dark cycle with ad libitum access to sterilized water. Starting at 1 month of age, the mice were divided into two groups: the Control group was fed with a Control diet (AIN-76 diet) ${ }^{19}(n=9)$, and the Mucuna group was fed with a diet containing Mucuna bean powder (Mucuna diet, $n=9$ ) for 13 months. The Mucuna bean powder used for preparing the Mucuna diet was processed as follows: Mucuna beans (whose chemical composition is shown in the Table S1), were of a gift from a farmer who had been cultivating this bean in Kumamoto 
prefecture in Japan. The written consent of the beans to be used for this research has been obtained. The use of the Mucuna beans in the present study complies applicable with international, national and /or institutional guidelines. The Mucuna beans were soaked in distilled water for $24 \mathrm{~h}$ and then autoclaved at $121^{\circ} \mathrm{C}$ for $40 \mathrm{~min}$, lyophilized, and milled (New Power Mill, Osaka Chemical Co., Ltd., Japan). The Mucuna bean powder contained $2.88 \%$ L-DOPA. The daily intake of L-DOPA derived from Mucuna bean powder was adjusted to $2 \mathrm{mg} / \mathrm{kg}$ body weight/day per mouse throughout the feeding period. The Mucuna bean powder content in the Mucuna diet varied from $0.028 \%$ to $0.091 \%$ in accordance with body weight. Body weight was monitored weekly. At the age of 14 months, mice were sacrificed under anesthesia with $200 \mathrm{mg} / \mathrm{kg}$ body weight of sodium pentobarbital delivered intraperitoneally, and the brain of each mouse was quickly harvested and sagittally bisected. The left hemisphere was fixed in $4 \%$ paraformaldehyde overnight for histological studies. The right hemisphere was dissected to isolate the striatum, hippocampus, and cerebral cortex and was stored at $-80^{\circ} \mathrm{C}$ for biochemical analyses.

All experiments reported herein were approved by the Animal Care Advisory Committee of Kagawa Nutrition University and were performed in accordance with the relevant guidelines and regulations (Permit Number: 18-2).

\section{Behavioral test: Y-maze test}

The Y-maze apparatus consisted of three arms (38 cm long, $12.5 \mathrm{~cm}$ wide, and $12.5 \mathrm{~cm}$ deep; Sanki Kagaku Kogei, Japan). Each mouse, at the age of 12 months, was placed at the center of the maze and allowed to freely explore the maze for $5 \mathrm{~min}$. An entry into an arm was considered complete when all four limbs were within the arm. An alteration was defined as three consecutive entries into three different arms $(A, B, C \text { or } B, C, A \text {, etc. })^{20}$. The percentage alteration score was calculated as follows: the total alteration number/(total number of entries -2$) \times 100$.

\section{Preparation of recombinant Tau protein}

Recombinant human tau protein (2N4R) CDNA in pET vectors was expressed in BL21 (DE3) Escherichia coli cells and purified as previously reported ${ }^{13}$. After E. coli expressing tau was sonicated and boiled, recombinant tau proteins in the heat-stable fraction were purified using ion-exchange chromatography (Cellufine Phosphate; JNC Corp), ammonium sulfate fractionation, gel filtration chromatography (NAP10 column; GE Healthcare), and reverse-phase HPLC (COSMOSIL-R Waters; Nacalai Tesque Inc.). After freeze-drying, recombinant tau proteins were dissolved in Milli-Q water and stored at $-80^{\circ} \mathrm{C}$.

\section{Thioflavin T assay}

Mucuna bean extracts for the Thioflavin T (ThT) assay were prepared as follows: Mucuna beans were incubated in distilled water at $100^{\circ} \mathrm{C}$ for $4 \mathrm{~h}$ and boiled for $1 \mathrm{~h}$. Boiled Mucuna beans were homogenized in $0.4 \mathrm{M}$ phosphate buffer $(\mathrm{pH}=4.0)$ and centrifuged $\left(9,000 \mathrm{rpm}, 10 \mathrm{~min}, 4^{\circ} \mathrm{C}\right)$. The supernatant was filtered through $0.45 \mu \mathrm{m}$ filters and subjected to a ThT assay. The ThT assay for $A \beta$ was performed as previously reported ${ }^{21}$. Mucuna bean extracts (extracted from $0.5 \mathrm{mg}$ or $5 \mathrm{mg}$ dried bean powder 
containing $10 \mu \mathrm{M}$ L-DOPA or $100 \mu \mathrm{M}$ L-DOPA), A $\beta_{1-42}(10 \mu \mathrm{M}$, PEPTIDE INSTITUTE, INC, Osaka, Japan), and ThT $(10 \mu \mathrm{M})$ were mixed in PBS and incubated at $37^{\circ} \mathrm{C}$. The ThT fluorescence intensity was recorded with an Ex/Em $=450 \mathrm{~nm} / 492 \mathrm{~nm}$ using a microplate-reader fluorometer (Corona Electric, Japan).

The ThT assay for tau was also performed as previously reported ${ }^{13}$. Recombinant wild-type 2N4R tau $(10 \mu \mathrm{M})$, Mucuna bean extracts (extracted from $0.5 \mathrm{mg}$ or $5 \mathrm{mg}$ dried bean powder containing $10 \mu \mathrm{M} \mathrm{L}-$ DOPA or $100 \mu \mathrm{M}$ L-DOPA), and ThT $(10 \mu \mathrm{M})$ were mixed in HEPES buffer (10 mM HEPES, $\mathrm{pH}=7.4 ; 100$ $\mathrm{mM} \mathrm{NaCl})$ and incubated with heparin $\left(0.06 \mathrm{mg} / \mathrm{ml}\right.$; Acros Organics) at $37^{\circ} \mathrm{C}$. The ThT fluorescence intensity was recorded every hour with an $\mathrm{Ex} / \mathrm{Em}=420 \mathrm{~nm} / 500 \mathrm{~nm}$ using a multiplate-reader fluorometer (1420 ARVO MX, Perkin Elmer). All samples were tested in triplicate.

\section{L-DOPA analyses}

The L-DOPA content of Mucuna bean extracts or powder was analyzed using a reversed-phase column WAKOSIL $₫ 5$ C18 RS $(\Phi 4.6 \times 250 \mathrm{~mm})$. This column was placed in a JASCO CO-2067 Plus HPLC column oven and analysis was conducted at $40^{\circ} \mathrm{C}$. The mobile phase was phosphate buffer $(\mathrm{pH}=2) /$ methanol (90:10) with a flow rate of $1 \mathrm{~mL} / \mathrm{min}$. The eluate was monitored at $200 \mathrm{~nm}$.

\section{Tissue extraction for biochemical studies}

Tissue extraction was performed as previously described ${ }^{13}$. Frozen brain tissues (striatum, hippocampus, and cerebral cortex) were homogenized in 7.5 volumes of TBS buffer containing $50 \mathrm{mM}$ Tris ( $\mathrm{pH}=7.4), 150 \mathrm{mM} \mathrm{NaCl}, 1 \mathrm{mM}$ EDTA, 1 mM EGTA, protease inhibitors, and phosphatase inhibitors. The homogenates were centrifuged $\left(23,000 \mathrm{rpm}, 15 \mathrm{~min}, 4^{\circ} \mathrm{C}\right)$ in a TLA-55 rotor (Beckman Coulter) and separated into the supernatant (TBS-soluble fraction) and pellet. The pellets were resuspended in $0.32 \mathrm{M}$ sucrose containing $10 \mathrm{mM}$ Tris $(\mathrm{pH}=7.4), 0.8 \mathrm{M} \mathrm{NaCl}$, and $1 \mathrm{mM}$ EGTA and were then centrifuged $\left(23,000 \mathrm{rpm}, 15 \mathrm{~min}, 4^{\circ} \mathrm{C}\right)$ in a TLA-55 rotor. Supernatants were collected and treated with $1 \%$ Sarkosyl for $1 \mathrm{~h}$ at $37^{\circ} \mathrm{C}$. They were then centrifuged $\left(60,000 \mathrm{rpm}, 1 \mathrm{~h}, 4^{\circ} \mathrm{C}\right)$ in a TLA-110 rotor and separated into the supernatant and pellet (Sarkosyl-insoluble fraction). Samples from TBS-soluble and Sarkosyl-insoluble fractions were dissolved in Laemmli SB including 2-mercaptoethanol and were then boiled for $5 \mathrm{~min}$.

\section{Immunoblotting analysis}

Immunoblotting analysis was performed as previously described ${ }^{22}$. The protein concentration of the TBS-soluble and Sarkosyl-insoluble fractions was determined using a DC protein assay kit (Bio-Rad, Hercules, CA, USA). Fifty-microgram protein from the TBS-soluble fraction was applied to NOVEX $10 \%-$ $20 \%$ Tricine gel (Thermo Fisher). The separated proteins were transferred to nitrocellulose membranes (Millipore, Billerica, MA, USA) and were subjected to heat treatment (boiling in PBS, 15 min). After blocking for 60 min at room temperature with $2.5 \%$ skim milk in PBS containing $0.05 \%$ Tween 20 , the membranes were incubated for $40 \mathrm{~h}$ at $4^{\circ} \mathrm{C}$ with primary antibody (6E10, 1:1000, BioLegend). After washing the membrane with PBS containing $0.05 \%$ Tween 20 , the blots were incubated with horseradish peroxidase-linked secondary antibodies at room temperature. Immune complexes were visualized by Western Lightning Ultra (Perkin Elmer). 
Thirty-microgram protein from the Sarkosyl-insoluble fraction was applied to NOVEX 5\%-20\% e-Pagel 1

\section{Immunohistochemistry}

Immunohistochemical analysis was performed as previously described ${ }^{22}$. The left hemisphere was fixed in $4 \%$ paraformaldehyde overnight. Paraffin-embedded sections (sectioned in the coronal plate at $4 \mu \mathrm{m}$ thick) were deparaffinized. For antigen retrieval, the sections for $A \beta$ were treated with proteinase $K$ (DAKO, S3004) for $10 \mathrm{~min}$ and then treated with $90 \%$ formic acid for $5 \mathrm{~min}$. The sections for phosphorylated tau were treated with Target Retrieval Solution (pH 9.0; DAKO, S2367) at $120^{\circ} \mathrm{C}$ for 10 min. Then, both sections were immersed in $0.3 \%$ hydrogen peroxide in methanol for 10 min. After treating with $5 \%$ normal rabbit serum for $10 \mathrm{~min}$, the sections were incubated overnight at $4^{\circ} \mathrm{C}$ with primary antibodies that were pre-mixed with secondary antibodies (anti-mouse lgG2b, goat Fab) at room temperature for 20 min. Primary antibodies for $A \beta$ and phosphorylated tau were 4G8 (1:1000, BioLegend) and AT8 (1:1000, Thermo Fisher Scientific), respectively. The secondary antibodies were visualized using a HistoFine kit (Nichirei, Japan), followed by a 3,3'-diaminobenzidine reaction. Finally, the sections were counterstained with hematoxylin and observed using an Olympus BX63 microscope equipped with an Olympus DP73 digital camera. Consecutive sections were incubated in the absence of primary antibodies to ensure the specificity of staining.

Quantification of the 4G8-positive A $\beta$ area and the AT8-positive tau area in the brain was performed using Image J-Fiji ( $(\mathrm{v}-1.45 \mathrm{NIH})$ after adjusting for the threshold, and the results were expressed as percentage of Control values.

\section{Statistical analysis}

Values are expressed as means \pm SD (or SEM). Differences were analyzed using Student's $t$-test, Welch's $t$-test, or one-way analysis of variance followed by Tukey's multiple comparisons test. Statistical significance was considered when $p<0.05$.

\section{Results}

\section{Mouse characteristics}

During this experiment, the Control group mice and the Mucuna group mice received a standard diet and a diet containing Mucuna bean powder, respectively, and body weight was determined weekly. As shown in Figure 1, body weight was not significantly different between the groups during the 13-month treatment.

All mice were weighed weekly from the beginning until the end of the study. Values are means \pm SD.

\section{Inhibition of $\mathbf{A} \beta$ aggregation and tau aggregation by Mucuna bean extracts}


The effect of Mucuna bean extracts on $A \beta$ aggregation and tau aggregation in vitro was examined using the ThT assay. This assay is based on monitoring the fluorescence change of ThT when binding to aggregated $A \beta$ and tau ${ }^{23}$. The intensity of fluorescence was determined in the presence of Mucuna bean extracts derived from $0.5 \mathrm{mg}$ or $5 \mathrm{mg}$ dried bean powder (containing $10 \mu \mathrm{M} \mathrm{L-DOPA}$ or $100 \mu \mathrm{M} \mathrm{L-DOPA}$ ). When Mucuna bean extracts were added to $A \beta_{1-42}$, the fluorescence intensity was suppressed in a dosedependent manner (Figure 2A). A dose-dependent reduction was also observed for heparin-induced ThT fluorescence when Mucuna bean extracts derived from $0.5 \mathrm{mg}$ or $5 \mathrm{mg}$ dried bean powder (containing 10 $\mu \mathrm{M}$ L-DOPA or $100 \mu \mathrm{M}$ L-DOPA) were added to recombinant wild-type-2N4R tau (Figure 2B). These results indicate that Mucuna bean extracts had an inhibitory effect on both $A \beta$ and tau aggregation in a dosedependent manner.

\section{Immunoblotting analysis of $A \beta$ and tau}

To investigate the effect of a Mucuna diet on $A \beta$ and tau aggregation in vivo, 3×Tg-AD mice were fed with a Mucuna diet for 13 months, starting at 1 month of age. After sacrificing, the striatum, hippocampus, and cerebral cortex were collected and homogenized. Homogenates were separated into a TBS-soluble fraction and a Sarkosyl-insoluble fraction. TBS-soluble fractions were subjected to immunoblotting analysis of $A \beta_{1-42}$. Significantly reduced levels of $A \beta_{1-42}$ tetramers and $A \beta_{1-42}$ octamers were observed in the hippocampi $(p<0.01)$ of the Mucuna group compared to those of the Control group (Figure 3 ). Significantly reduced levels of $A \beta_{1-42}$ tetramers were also observed in the cerebral cortexes $(p<0.01)$ of

the Mucuna group compared to those of the Control group (Figure 3). However, levels of $A \beta_{1-42}$ tetramers in the striatum of the Mucuna group were not significantly different from those of the Control group. $A \beta_{1}$. 42 octamers were not detected in the cerebral cortex and striatum.

Sarkosyl-insoluble fractions were subjected to immunoblotting analysis of phosphorylated tau. Phosphorylated tau levels were found to be significantly reduced in the striatum $(p<0.05)$ and cerebral cortex $(p<0.05)$ from the Mucuna group as compared to those from the Control group (Figure 4$)$. In the hippocampi of the Mucuna group, the phosphorylated tau levels tended to be lower but did not reach statistical significance. These results indicate that $A \beta$ and tau aggregation were suppressed in the Mucuna group.

\section{Immunohistochemistry of $A \beta$ and phosphorylated tau accumulation}

To test whether a Mucuna diet affects $A \beta$ and phosphorylated tau accumulation in the brain, immunohistochemical analysis was performed. $4 G 8$ antibody-positive $A \beta$ accumulation was observed in the fimbria, cerebral cortex, and the vicinity of the amygdala. $A \beta$ accumulation in the Mucuna group was significantly lower than that of the Control group (Figure 5, $p<0.05$ ). A significant reduction of AT8 antibody-positive phosphorylated tau accumulation was mainly observed in the fimbria and cerebral cortex. Phosphorylated tau accumulation in the Mucuna group was significantly lower than that of the Control group (Figure $6, p<0.05$ ). These data indicate that $A \beta$ and phosphorylated tau accumulation in the brain was suppressed in the Mucuna group. 


\section{Behavioral test: Y-maze}

To determine the effect of the Mucuna diet on spatial working memory, mice were tested using a Y-maze apparatus at 12 months of age. The Y-maze test is a behavioral test to evaluate the spatial working memory (as measured by the percentage of alteration) and the locomotor activity (as measured by the number of entries) ${ }^{20}$. There were no significant differences in the number of entries between the Control group and the Mucuna group. However, the percentage of alteration was higher in the Mucuna group than in the Control group (Figure 7, $p<0.05$ ). These data suggest that administration of Mucuna beans improved behavioral performance related to spatial working memory without changes in locomotor activity.

\section{Discussion}

The present study was conducted to investigate the biological effect of Mucuna bean administration on AD prevention in 3×Tg-AD mice. Since Mucuna beans contain 3\%-9\% of L-DOPA, a large intake of Mucuna beans causes gastrointestinal disturbances, including vomiting ${ }^{16}$. Therefore, in the present study, the dose level of L-DOPA in the Mucuna diet was adjusted to $2 \mathrm{mg} / \mathrm{kg}$ weight/day during the feeding period. The growth curve of the Mucuna group was nearly the same as that of the Control group over the treatment period. This result implies that the dose level of L-DOPA was appropriate.

Various polyphenols derived from foods, including quercetin, RA, myricetin, and epigallocatechin gallate, have been reported to inhibit $A \beta$ aggregation in vitro ${ }^{24} 25$. The phenolic hydroxyl groups of polyphenols, especially the catechol skeleton (1,2-dihydroxybenzene), are essential for the inhibition of $A \beta$ aggregation in vitro ${ }^{26}$. Polyphenols with a catechol skeleton undergo autoxidation, generating $o$-quinones, which react with nucleophilic amino acid residues, including Cys (sulfhydryl groups; $\mathrm{SH}$ ) and Lys (free amino groups; $\left.\mathrm{NH}_{2}\right)^{27}$. Generated $o$-quinones covalently bind to the Lys 16 and Lys28 residues of $A \beta_{1-42}$, resulting in destabilization of $A \beta_{1-42}$ aggregates ${ }^{26}$. Meanwhile, using ThT assay, recent studies have shown that LDOPA, which also has a catechol skeleton, inhibits $A \beta_{1-42}$ aggregation in vitro ${ }^{12}{ }^{28}$. In the present study, Mucuna bean extracts inhibited $A \beta$ aggregation dose-dependently in vitro (Figure $2 A$ ). This result suggests that the L-DOPA in Mucuna bean extracts might be autoxidized to dopaquinones and bind to $A \beta_{1-42}$, resulting in the inhibition of $A \beta_{1-42}$ aggregation.

It has been reported that monoamines with a catechol skeleton (1,2-dihydroxybenzene) including L-DOPA, $\mathrm{DA}, \mathrm{NE}$, and epinephrine inhibit tau aggregation in vitro ${ }^{13}$. However, compounds with a 1-hydroxybenzene skeleton, including octopamine and 3-methoxytyramine did not inhibit tau aggregation ${ }^{13}$. Therefore, the catechol skeleton plays an important role in the inhibition of tau aggregation. The underlying mechanism for the inhibition of tau aggregation is thought to be as follows: compounds with a catechol skeleton bind and interact with Cys residues of tau and prevent disulfide bonding between Cys residues in tau ${ }^{13}$. In the present study, Mucuna bean extracts also dose-dependently inhibited tau aggregation (Figure 2B). 
Thus, it is likely that L-DOPA in Mucuna bean extracts might contribute to the inhibition of tau aggregation through interaction with the Cys residues of tau.

In the mice treated with Mucuna diet, a significant decrease in $A \beta_{1-42}$ tetramer and octamer levels in the hippocampus was detected by immunoblotting analysis in the TBS-soluble fraction (Figure 3). Octamers are formed by two tetramers facing each other ${ }^{29}$. Soluble $A \beta$ oligomers play a role in initiating cognitive impairment ${ }^{2} 3031$. For example, repeated hippocampal injections of low-order $A \beta_{1-42}$ oligomers in the brain of awake mice caused neuronal loss, tau hyperphosphorylation, and memory deficits ${ }^{32,33}$. Loworder $A \beta$ oligomers have the basic structure of protofibrils, and their neurotoxicity becomes more severe with oligomer order ${ }^{34}$. Regarding the mechanism underlying neurotoxicity of $A \beta$ oligomers, several hypotheses have been proposed. For example, $A \beta$ oligomers form ion channels when embedded into the cell membrane to cause an abnormal ion flux through the membrane, inducing cell death ${ }^{35} 36,37$. Recently, Ciudad et al. demonstrated that $A \beta_{1-42}$ tetramers and octamers form pores within the membrane mimicking the lipid bilayer, which lead to membrane disruption by allowing water to permeate ${ }^{29}$. These results suggest that a diet containing Mucuna might contribute to the maintenance of neuronal membrane integrity by reducing the $A \beta_{1-42}$ tetramer and octamer levels.

In the present study, immunoblotting analysis showed that the levels of phosphorylated tau in the Sarkosyl-insoluble fraction were lower in the brain of mice from the Mucuna group. Phosphorylated tau in the Sarkosyl-insoluble fraction is neurotoxic and potently linked to neuronal loss in the brain of AD-model mice ${ }^{38}$. It has been reported that isoproterenol, an adrenergic receptor agonist that has a catechol skeleton structure, inhibits tau aggregation in vitro. Moreover, administration of isoproterenol reduced the levels of phosphorylated tau in the Sarkosyl-insoluble fraction and neuronal loss in the brain of P301L tau-transgenic mice ${ }^{13}$. The catechol skeleton of isoproterenol is responsible for inhibiting tau aggregation through the interaction with Cys residues of tau ${ }^{13}$. These results suggest that L-DOPA in Mucuna beans might contribute to the reduction in phosphorylated tau levels in the Sarkosyl-insoluble fraction via inhibition of tau aggregation in the brain of mice from the Mucuna group.

After administration, L-DOPA is metabolized in the brain to monoamines, including DA, DOPAC, and NE, all of which have a catechol skeleton. Yadav et al. treated Parkinson's disease (PD) model mice with Mucuna beans and found that the levels of DA and DOPAC increased in the nigrostriatal region ${ }^{39}$. They also indicated that Mucuna beans have neuroprotective activity via reduction of oxidative stress ${ }^{39}$. The concentration ratio of monoamines in the cerebral cortex of the mouse treated with RA was approximately 100:10:30:1 DA: DOPAC: NE: L-DOPA ${ }^{12}$. These results suggest that L-DOPA in a Mucuna diet is metabolized to monoamines, including DA, DOPAC, and NE, and, together with any residual LDOPA, its metabolites inhibit the aggregation of both tau and $A \beta$ in the brain, leading to the reduction of phosphorylated tau and $A \beta$ oligomers.

$A \beta$ accumulation in the brain of $3 \times T g-A D$ mice begins to appear in the cortex at the age of 6 months and progresses to the hippocampus ${ }^{17}{ }^{18}$. Phosphorylated tau accumulation appears in the hippocampus at 
the age of 12 months and progresses to the cerebral cortex ${ }^{17}{ }^{18}$. Injection of $A \beta$ oligomers to the brain of $A D$-model mice has been reported to promote $A D$ pathology, including $A \beta$ accumulation ${ }^{32}$. Conversely, a reduction of $A \beta$ accumulation was observed in $A D$-model mice receiving passive immunization with antioligomeric antibodies ${ }^{40}$. In the present study, immunoblotting analysis showed a reduction in $A \beta_{1-42}$ tetramer and octamer levels in the brain of mice from the Mucuna group. Therefore, suppression of $A \beta$ accumulation in the brain of these mice might be affected by the reduction in $A \beta_{1-42}$ tetramer and octamer levels. Phosphorylated tau accumulation, observed mainly in the fimbria and cerebral cortex, was also suppressed in the brain of Mucuna group mice. $A \beta$ accumulation was also observed in the fimbria and cerebral cortex. The fimbria, the nerve fiber bundle along the medial edge of the hippocampus, plays a role in controlling spatial working memory; therefore, fimbria lesions induce a decline in spatial working memory ${ }^{41}$. To evaluate the spatial working memory, the Y-maze test was performed ${ }^{20}$. In the present study, mice in the Mucuna group improved behavioral performance related to spatial working memory compared with those in the control group. These results imply that suppression of $A \beta$ and phosphorylated tau accumulation might lead to an improvement in spatial working memory. These results also suggest that Mucuna diet may have protective effects on memory function. However, other tests, including a passive avoidance test and a novel object recognition test, should also be conducted to further confirm the result.

Mucuna bean powder has been used for the treatment of PD as the alternative medicine Levodopa (pharmaceutical formulation of L-DOPA) in India. As noted above, a high intake of Mucuna beans sometimes causes nausea and vomiting due to the high L-DOPA content. Sixty PD patients were administered $45 \mathrm{~g} /$ person/day of Mucuna bean powder (containing $1.5 \mathrm{~g}$ of L-DOPA) for 12 weeks ${ }^{16}$. Side effects of Mucuna bean powder mainly included mild nausea. Additionally, nine PD patients received $30 \mathrm{~g}$ of Mucuna bean powder (containing $1 \mathrm{~g}$ of L-DOPA) at once, and then side effects were monitored over the next $240 \mathrm{~min}$. Short-lasting vomiting occurred in one patient, and short-lasting nausea occurred in two patients ${ }^{42}$. No significant changes in hematology or biochemical parameters were observed. However, no information is available on tolerability of Mucuna bean consumption in healthy subjects. Therefore, caution is needed regarding the intake of Mucuna bean powder used as a pharmacological dose. Furthermore, some polyphenols are reported to have a potential impact on oxidative damage ${ }^{43}$. Recently, lijima et al. investigated the optimum processing conditions to control the L-DOPA content in Mucuna beans ${ }^{44}$. The content of L-DOPA decreased to approximately $25 \%-40 \%$ by processing procedures, while $50 \%-90 \%$ of the other soluble components remained ${ }^{44}$. lijima et al. also developed palatable and nutritious foods using Mucuna beans 454647 . However, further investigations are needed to clarify the preventive effects of Mucuna beans on $A D$ in humans.

To our knowledge, the present study is the first report that revealed preventive effects of Mucuna beans against AD. Administration of Mucuna beans reduced the levels of $A \beta$ oligomers and detergent-insoluble phosphorylated tau, reduced $A \beta$ accumulation and phosphorylated tau accumulation in the brain, and 
improved memory function in $3 \times \mathrm{Tg}-\mathrm{AD}$ mice. These results suggest that Mucuna beans are a candidate food expected to have a preventive effect on $A D$ development.

\section{Abbreviations}

AD Alzheimer's disease

$A \beta$ amyloid-beta peptides

NFTs neurofibrillary tangles

L-DOPA L-3,4-dihydroxyphenylalanine

DA dopamine

NE norepinephrine

DOPAC 3,4-dihydroxyphenylacetic acid

APPswe amyloid precursor protein Swedish

PS1 presenilin-1

ThT Thioflavin T

EDTA ethylenediaminetetraacetic acid

EGTA ethylene glycol tetraacetic acid

TBS Tris-buffered saline

PBS phosphate-buffered saline

PD Parkinson's disease

HPLC High-performance liquid chromatography

\section{Declarations}

\section{Acknowledgement}

We thank the staff of the Support Center for Medical Research and Education of Tokai University for technical assistances.

\section{Funding source}


This work was supported by the Japan Society for the Promotion of Science, a Grant-Aid for C (No. 16K00824).

\section{References}

1. Ballard, C. et al. Alzheimer's disease., 377, 1019-1031 https://doi.org/10.1016/s01406736(10)61349-9 (2011).

2. Ono, K. Alzheimer's disease as oligomeropathy. Neurochem Int, 119, 57-70 https://doi.org/10.1016/j.neuint.2017.08.010 (2018).

3. Roychaudhuri, R., Yang, M., Hoshi, M. M. \& Teplow, D. B. Amyloid beta-protein assembly and Alzheimer disease. J Biol Chem, 284, 4749-4753 https://doi.org/10.1074/jbc.R800036200 (2009).

4. Shankar, G. M. et al. Amyloid-beta protein dimers isolated directly from Alzheimer's brains impair synaptic plasticity and memory. Nat Med, 14, 837-842 https://doi.org/10.1038/nm1782 (2008).

5. Santos, A. N. et al. Amyloid- $\beta$ oligomers in cerebrospinal fluid are associated with cognitive decline in patients with Alzheimer's disease. J Alzheimers Dis, 29, 171-176 https://doi.org/10.3233/jad-2012111361 (2012).

6. Haass, C. \& Selkoe, D. J. Soluble protein oligomers in neurodegeneration: lessons from the Alzheimer's amyloid beta-peptide. Nat Rev Mol Cell Biol, 8, 101-112 https://doi.org/10.1038/nrm2101 (2007).

7. Mietelska-Porowska, A., Wasik, U., Goras, M., Filipek, A. \& Niewiadomska, G. Tau protein modifications and interactions: their role in function and dysfunction. Int J Mol Sci, 15, 4671-4713 https://doi.org/10.3390/ijms15034671 (2014).

8. Soeda, Y. et al. Methylene Blue Inhibits Formation of Tau Fibrils but not of Granular Tau Oligomers: A Plausible Key to Understanding Failure of a Clinical Trial for Alzheimer's Disease. J Alzheimers Dis, 68, 1677-1686 https://doi.org/10.3233/jad-181001 (2019).

9. Kimura, T. et al. Hyperphosphorylated tau in parahippocampal cortex impairs place learning in aged mice expressing wild-type human tau. Embo j, 26, 5143-5152 https://doi.org/10.1038/sj.emboj.7601917 (2007).

10. Kimura, T. et al. Aggregation of detergent-insoluble tau is involved in neuronal loss but not in synaptic loss. J Biol Chem, 285, 38692-38699 https://doi.org/10.1074/jbc.M110.136630 (2010).

11. Hamaguchi, T., Ono, K., Murase, A. \& Yamada, M. Phenolic compounds prevent Alzheimer's pathology through different effects on the amyloid-beta aggregation pathway. Am J Pathol, 175, 2557-2565 https://doi.org/10.2353/ajpath.2009.090417 (2009).

12. Hase, T. et al. Rosmarinic acid suppresses Alzheimer's disease development by reducing amyloid $\beta$ aggregation by increasing monoamine secretion. Sci Rep, 9, $8711 \mathrm{https} / / /$ doi.org/10.1038/s41598019-45168-1 (2019).

13. Soeda, Y. et al. Toxic tau oligomer formation blocked by capping of cysteine residues with 1,2dihydroxybenzene groups. Nat Commun, 6, 10216 https://doi.org/10.1038/ncomms10216 (2015). 
14. FUJII Y., S. T., YASUDA T.. L-3, 4-Dihydroxyphenylalanine as an Allelochemical Candidate from Mucuna pruriens (L.) DC. var. utilis.Agric. Biol. Chem.55,617-618(1991).

15. Bell, E. A. \& Janzen, D. H. Medical and ecological considerations of L-dopa and 5-HTP in seeds. Nature, 229, 136-137 https://doi.org/10.1038/229136a0 (1971).

16. An alternative medicine. treatment for Parkinson's disease: results of a multicenter clinical trial. HP200 in Parkinson's Disease Study Group. J Altern Complement Med, 1, 249-255 https://doi.org/10.1089/acm.1995.1.249 (1995).

17. Oddo, S. et al. Triple-transgenic model of Alzheimer's disease with plaques and tangles: intracellular Abeta and synaptic dysfunction., 39, 409-421 https://doi.org/10.1016/s0896-6273(03)00434-3 (2003).

18. Oddo, S., Caccamo, A., Kitazawa, M., Tseng, B. P. \& LaFerla, F. M. Amyloid deposition precedes tangle formation in a triple transgenic model of Alzheimer's disease. Neurobiol Aging, 24, 1063-1070 https://doi.org/10.1016/j.neurobiolaging.2003.08.012 (2003).

19. Bieri, J. G. AlN-76 diet. J Nutr, 109, 925-926 https://doi.org/10.1093/jn/109.5.925 (1979).

20. Magistri, M. et al. The BET-Bromodomain Inhibitor JQ1 Reduces Inflammation and Tau Phosphorylation at Ser396 in the Brain of the 3xTg Model of Alzheimer's Disease. Curr Alzheimer Res, 13, 985-995 https://doi.org/10.2174/1567205013666160427101832 (2016).

21. Yoshiike, Y. et al. New insights on how metals disrupt amyloid beta-aggregation and their effects on amyloid-beta cytotoxicity. J Biol Chem, 276, 32293-32299 https://doi.org/10.1074/jbc.M010706200 (2001).

22. Horikoshi, Y. et al. Aberrant activation of atypical protein kinase $\mathrm{C}$ in carbon tetrachloride-induced oxidative stress provokes a disturbance of cell polarity and sealing of bile canalicular lumen. $\mathrm{Am} \mathrm{J}$ Pathol, 185, 958-968 https://doi.org/10.1016/j.ajpath.2014.12.015 (2015).

23. Khurana, R. et al. Mechanism of thioflavin T binding to amyloid fibrils. J Struct Biol, 151, 229-238 https://doi.org/10.1016/j.jsb.2005.06.006 (2005).

24. Ono, K. et al. Potent anti-amyloidogenic and fibril-destabilizing effects of polyphenols in vitro: implications for the prevention and therapeutics of Alzheimer's disease. J Neurochem, 87, 172-181 https://doi.org/10.1046/j.1471-4159.2003.01976.x (2003).

25. Ogawa, K. et al. Spearmint Extract Containing Rosmarinic Acid Suppresses Amyloid Fibril Formation of Proteins Associated with Dementia. Nutrients, 12, https://doi.org/10.3390/nu12113480 (2020).

26. Sato, M. et al. Site-specific inhibitory mechanism for amyloid $\beta 42$ aggregation by catechol-type flavonoids targeting the Lys residues. J Biol Chem, 288, 23212-23224 https://doi.org/10.1074/jbc.M113.464222 (2013).

27. Palhano, F. L., Lee, J., Grimster, N. P. \& Kelly, J. W. Toward the molecular mechanism(s) by which EGCG treatment remodels mature amyloid fibrils. J Am Chem Soc, 135, 7503-7510 https://doi.org/10.1021/ja3115696 (2013).

28. Huong, V. T. et al. Catechol derivatives inhibit the fibril formation of amyloid-beta peptides. J Biosci Bioeng, 109, 629-634 https://doi.org/10.1016/j.jbiosc.2009.11.010 (2010). 
29. Ciudad, S. et al. $A \beta(1-42)$ tetramer and octamer structures reveal edge conductivity pores as a mechanism for membrane damage. Nat Commun, 11, 3014 https://doi.org/10.1038/s41467-02016566-1 (2020).

30. Ono, K. \& Yamada, M. Low-n oligomers as therapeutic targets of Alzheimer's disease. J Neurochem, 117, 19-28 https://doi.org/10.1111/j.1471-4159.2011.07187.x (2011).

31. Tanokashira, D. et al. The neurotoxicity of amyloid $\beta$-protein oligomers is reversible in a primary neuron model. Mol Brain, 10, 4 https://doi.org/10.1186/s13041-016-0284-5 (2017).

32. Brouillette, J. et al. Neurotoxicity and memory deficits induced by soluble low-molecular-weight amyloid- $\beta 1-42$ oligomers are revealed in vivo by using a novel animal model. $J$ Neurosci, 32, 7852$7861 \mathrm{https} / / /$ doi.org/10.1523/jneurosci.5901-11.2012 (2012).

33. Ma, Q. L. et al. Beta-amyloid oligomers induce phosphorylation of tau and inactivation of insulin receptor substrate via c-Jun $\mathrm{N}$-terminal kinase signaling: suppression by omega-3 fatty acids and curcumin. J Neurosci, 29, 9078-9089 https://doi.org/10.1523/jneurosci.1071-09.2009 (2009).

34. Ono, K., Condron, M. M. \& Teplow, D. B. Structure-neurotoxicity relationships of amyloid beta-protein oligomers. Proc Natl Acad Sci U S A, 106, 14745-14750 https://doi.org/10.1073/pnas.0905127106 (2009).

35. Kagan, B. L., Hirakura, Y., Azimov, R., Azimova, R. \& Lin, M. C. The channel hypothesis of Alzheimer's disease: current status., 23, 1311-1315 https://doi.org/10.1016/s0196-9781(02)00067-0 (2002).

36. Shirwany, N. A., Payette, D., Xie, J. \& Guo, Q. The amyloid beta ion channel hypothesis of Alzheimer's disease. Neuropsychiatr Dis Treat, 3, 597-612 (2007).

37. Voelker, M. J., Barz, B. \& Urbanc, B. Fully Atomistic $A \beta 40$ and $A \beta 42$ Oligomers in Water: Observation of Porelike Conformations. J Chem Theory Comput, 13, 4567-4583 https://doi.org/10.1021/acs.jctc.7b00495 (2017).

38. Ren, Y. \& Sahara, N. Characteristics of tau oligomers. Front Neurol, 4, 102 https://doi.org/10.3389/fneur.2013.00102 (2013).

39. Yadav, S. K. et al. Comparison of the neuroprotective potential of Mucuna pruriens seed extract with estrogen in 1-methyl-4-phenyl-1,2,3,6-tetrahydropyridine (MPTP)-induced PD mice model. Neurochem Int, 65, 1-13 https://doi.org/10.1016/j.neuint.2013.12.001 (2014).

40. Rasool, S., Martinez-Coria, H., Wu, J. W., LaFerla, F. \& Glabe, C. G. Systemic vaccination with antioligomeric monoclonal antibodies improves cognitive function by reducing $A \beta$ deposition and tau pathology in 3xTg-AD mice. J Neurochem, 126, 473-482 https://doi.org/10.1111/jnc.12305 (2013).

41. Almaguer-Melian, W. et al. Erythropoietin Promotes Neural Plasticity and Spatial Memory Recovery in Fimbria-Fornix-Lesioned Rats. Neurorehabil Neural Repair, 29, 979-988 https://doi.org/10.1177/1545968315572389 (2015).

42. Katzenschlager, R. et al. Mucuna pruriens in Parkinson's disease: a double blind clinical and pharmacological study. J Neurol Neurosurg Psychiatry, 75, 1672-1677 https://doi.org/10.1136/jnnp.2003.028761 (2004). 
43. Kobayashi, H., Murata, M., Kawanishi, S. \& Oikawa, S. Polyphenols with Anti-Amyloid $\beta$ Aggregation Show Potential Risk of Toxicity Via Pro-Oxidant Properties. Int J Mol Sci, 21, https://doi.org/10.3390/ijms21103561 (2020).

44. lijima, K., Fujii, K. M. \& Kasai, Y. M. Effect of Various Cooking Conditions on the Amount of Proximate Components and L-DOPA in Mucuna Beans. J. Cookery Sci. Jpn, 45, 438-446 (2012).

45. lijima, K. \& Fujii, U. A. Y. Utilization of Mucuna Beans for Bean Paste and Cooked Beans. J. Jpn. Soc. Home Econ, 64, 117-124 (2013).

46. Koriyama, T., Konishi, I. K., Sato, F. \& Kasai, Y. M. Study on Preparation Conditions and Changes in Antioxidant Activity of Mucuna Bean Miso. J. Cookery Sci. Jpn, 50, 174-181 (2017).

47. Koriyama, T., Ehara, I. K., Konishi, M. \& Kasai, F. M. Effect of Sodium Bicarbonate on L-DOPA in Cooked Mucuna Bean Products. J. Jpn. Soc. Home Econ, 71, 392-400 (2020).

\section{Figures}

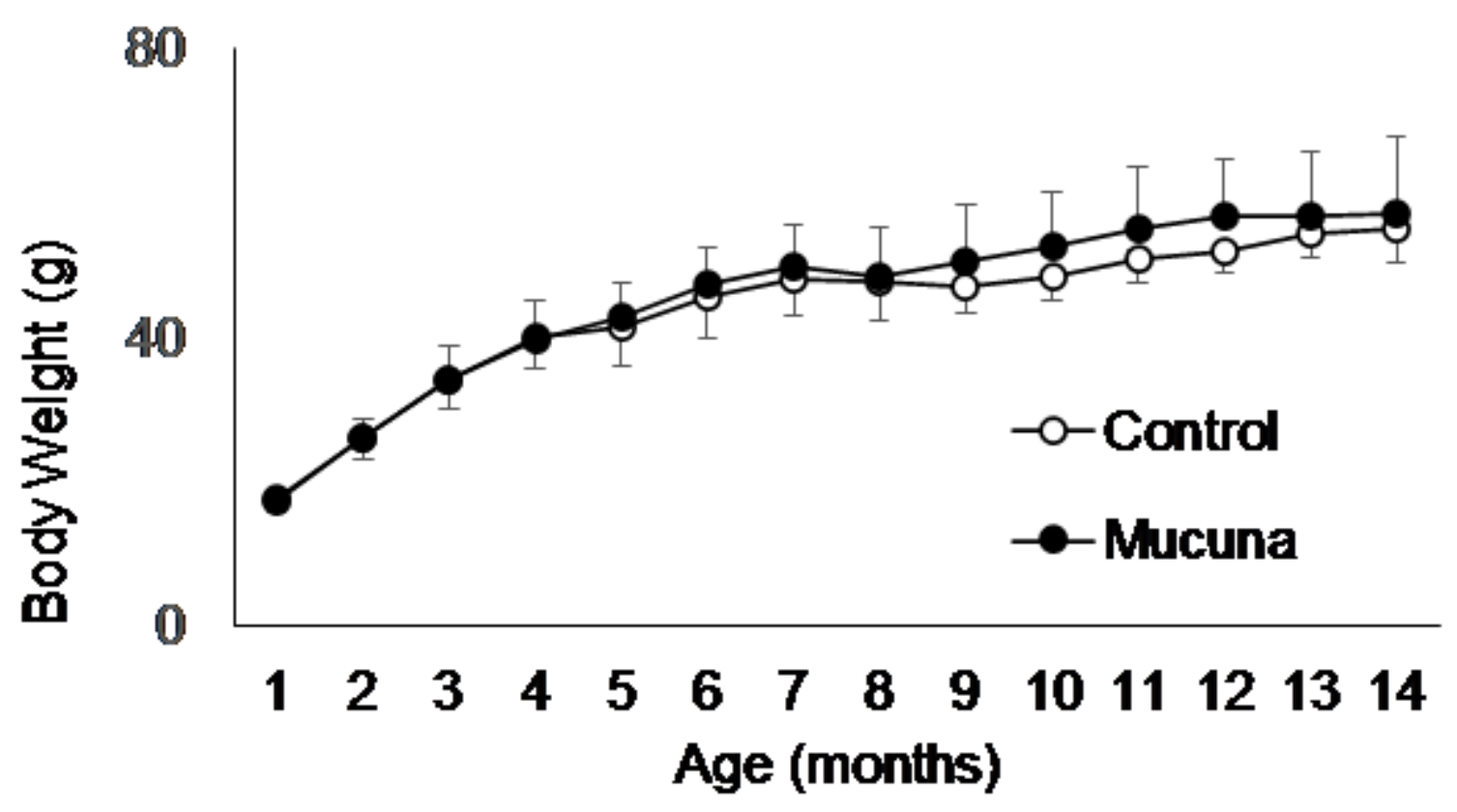

Figure 1.

Figure 1

Monitoring the body weight of Mucuna-treated mice. All mice were weighed weekly from the beginning until the end of the study. Values are means \pm SD. 
A

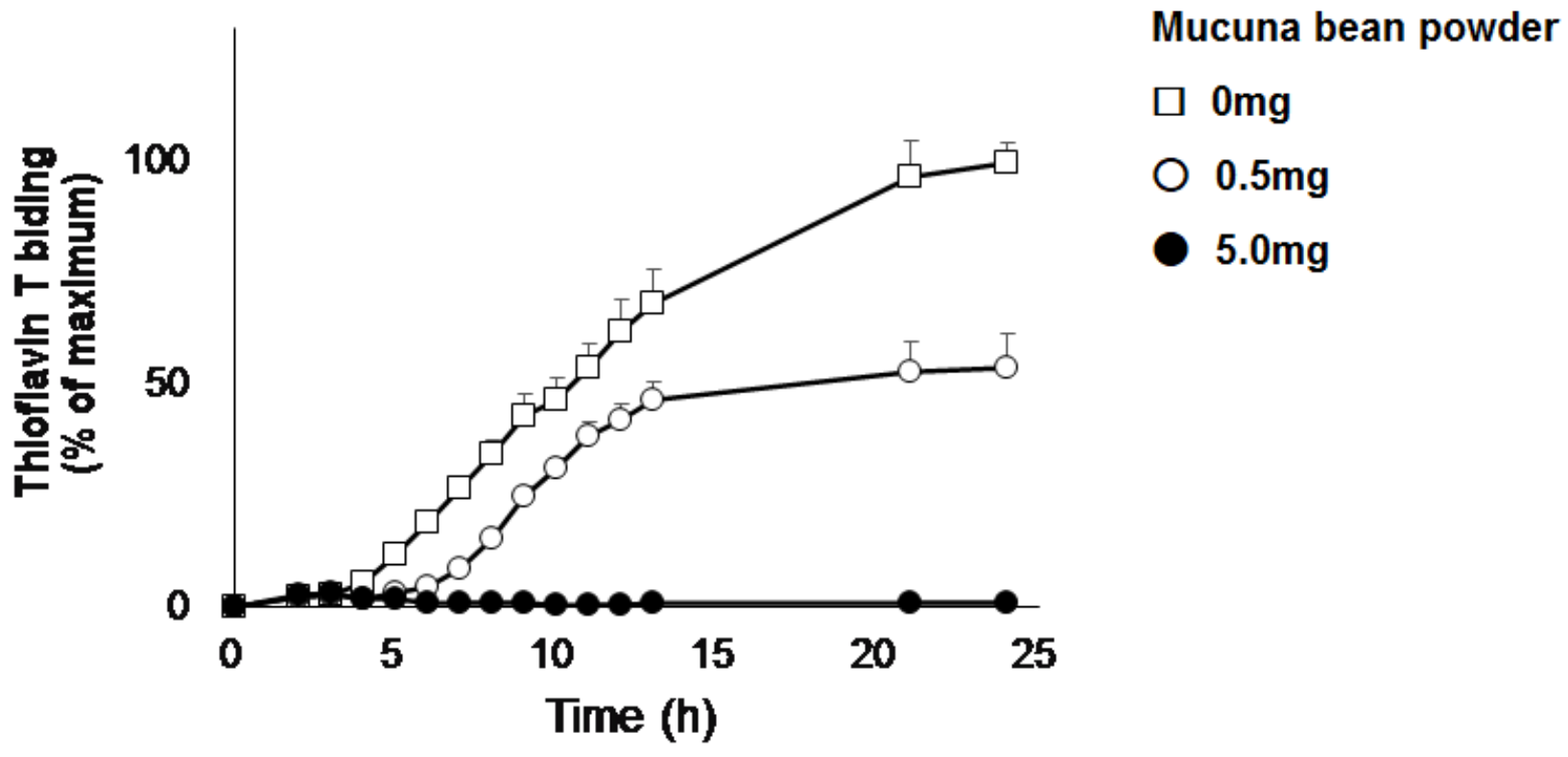

B

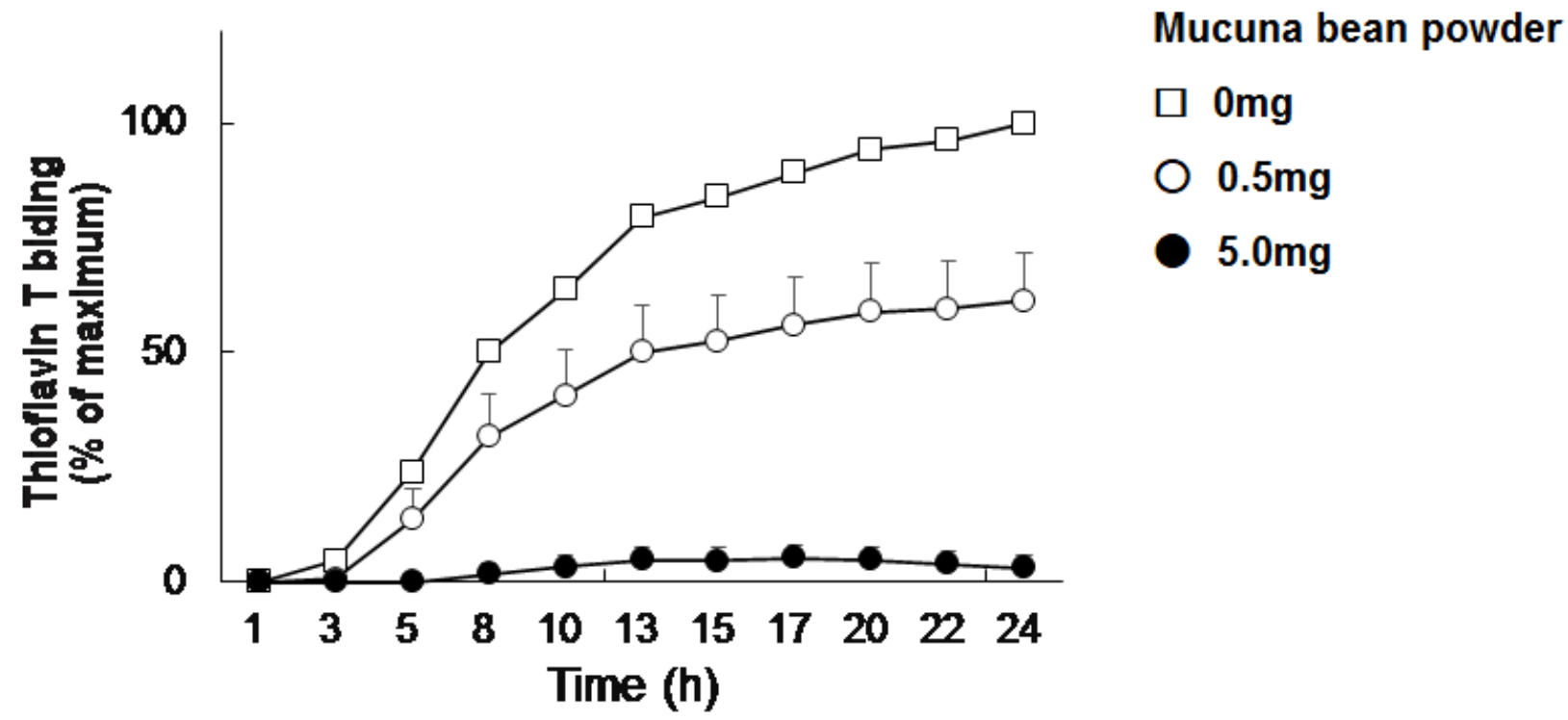

Figure 2.

Figure 2

Inhibitory effect of Mucuna bean extracts on $A \beta$ aggregation (A) and tau aggregation (B). (A) The effect of Mucuna bean extracts on $A \beta$ aggregation was examined. Mucuna bean extracts were extracted with $0.4 \mathrm{M}$ phosphate buffer ( $\mathrm{pH}$ 4.0) from Mucuna bean powder. Mucuna bean extracts significantly inhibited $A \beta$ aggregation at $9-25 \mathrm{~h}(\mathrm{p}<0.05)$. Results are expressed as percentage of maximum fluorescence (means \pm SD of triplicate experiments; $n=3$ ). (B) The effect of Mucuna bean extracts on tau aggregation 
was examined. Mucuna bean extracts significantly inhibited tau aggregation at $5-24 \mathrm{~h}(\mathrm{p}<0.05)$. Results are expressed as percentage of maximum fluorescence (means \pm SD of triplicate experiments; $n=3$ ). $\square$ : extracted from $0 \mathrm{mg}$ Mucuna bean powder; $\bullet$ : extracted from $0.5 \mathrm{mg}$ Mucuna bean powder; $\bullet$ : extracted from $5.0 \mathrm{mg}$ Mucuna bean powder.

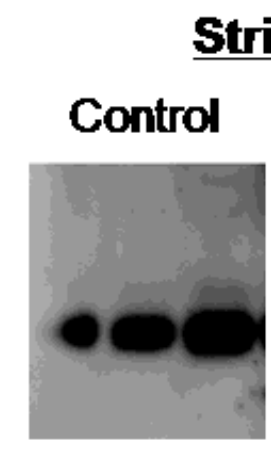

Striatum

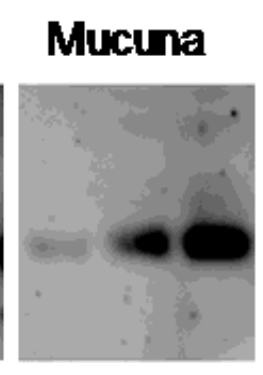

Cerebral cortex

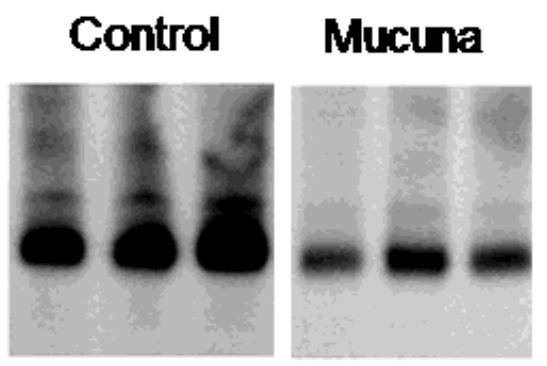

Hippocampus

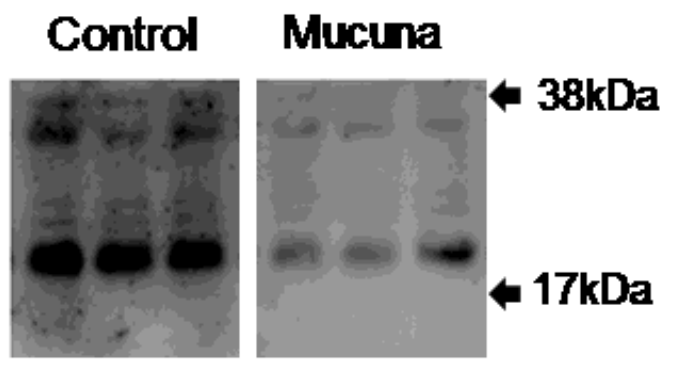

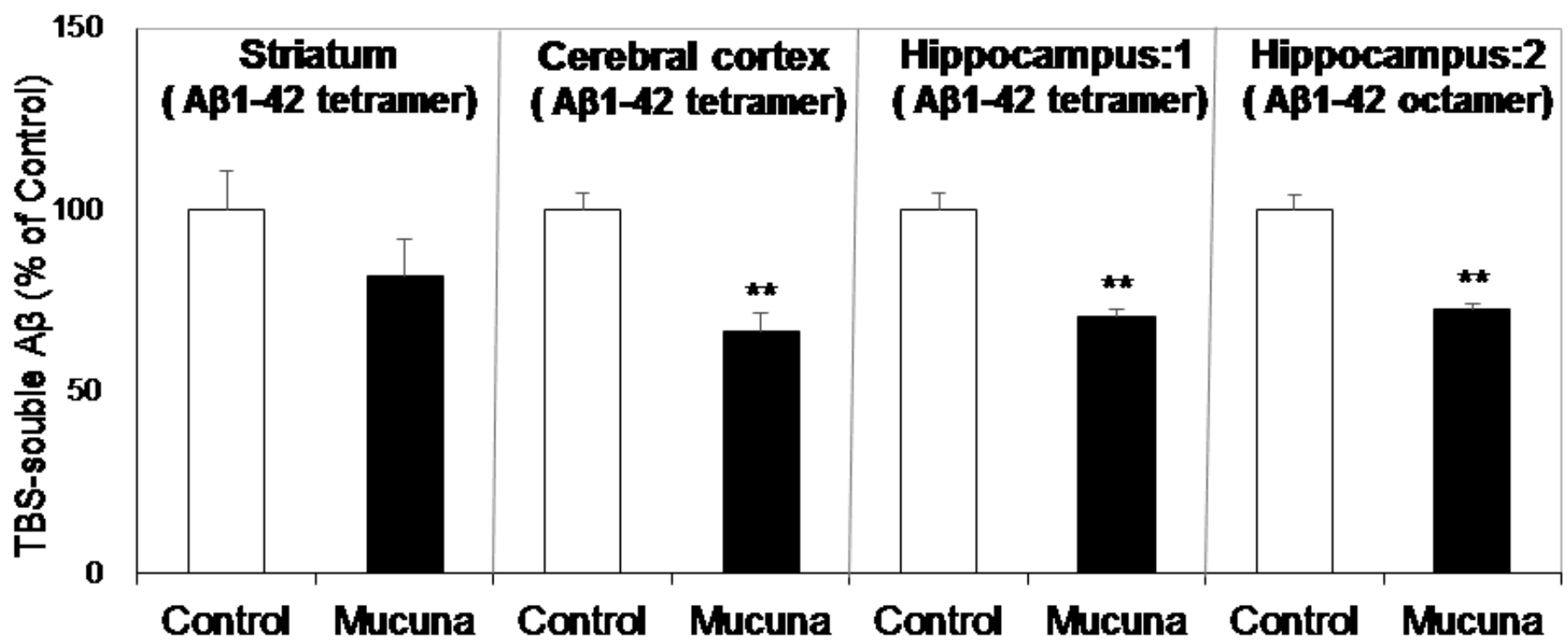

Figure 3.

Figure 3

Immunoblotting analysis of A $\beta$ oligomers in the TBS-soluble fraction. TBS-soluble fractions were obtained from the striatum, cerebral cortex, and hippocampus homogenates from $3 \times \mathrm{Tg}-\mathrm{AD}$ mice fed with the Mucuna diet (Mucuna group) or the Control diet (Control group). Levels of TBS-soluble A $\beta$ oligomers were analyzed by immunoblotting using 6E10 antibodies and quantified. Hippocampus:1 shows AB1-42 tetramers; Hippocampus:2 shows A 1 1-42 octamers. Densitometry of $A \beta$ oligomer immunoreactivity was quantified. Results are shown as percentage of Control values (means $\pm S E M, n=4$ ). ${ }^{\star \star} p<0.01$ versus Control by Student's t-test. 
Striatum

Control

Cerebral cortex

Hippocampus
Mucuna

$50 \mathrm{kDa}$

50kDa

$50 \mathrm{kDa}$

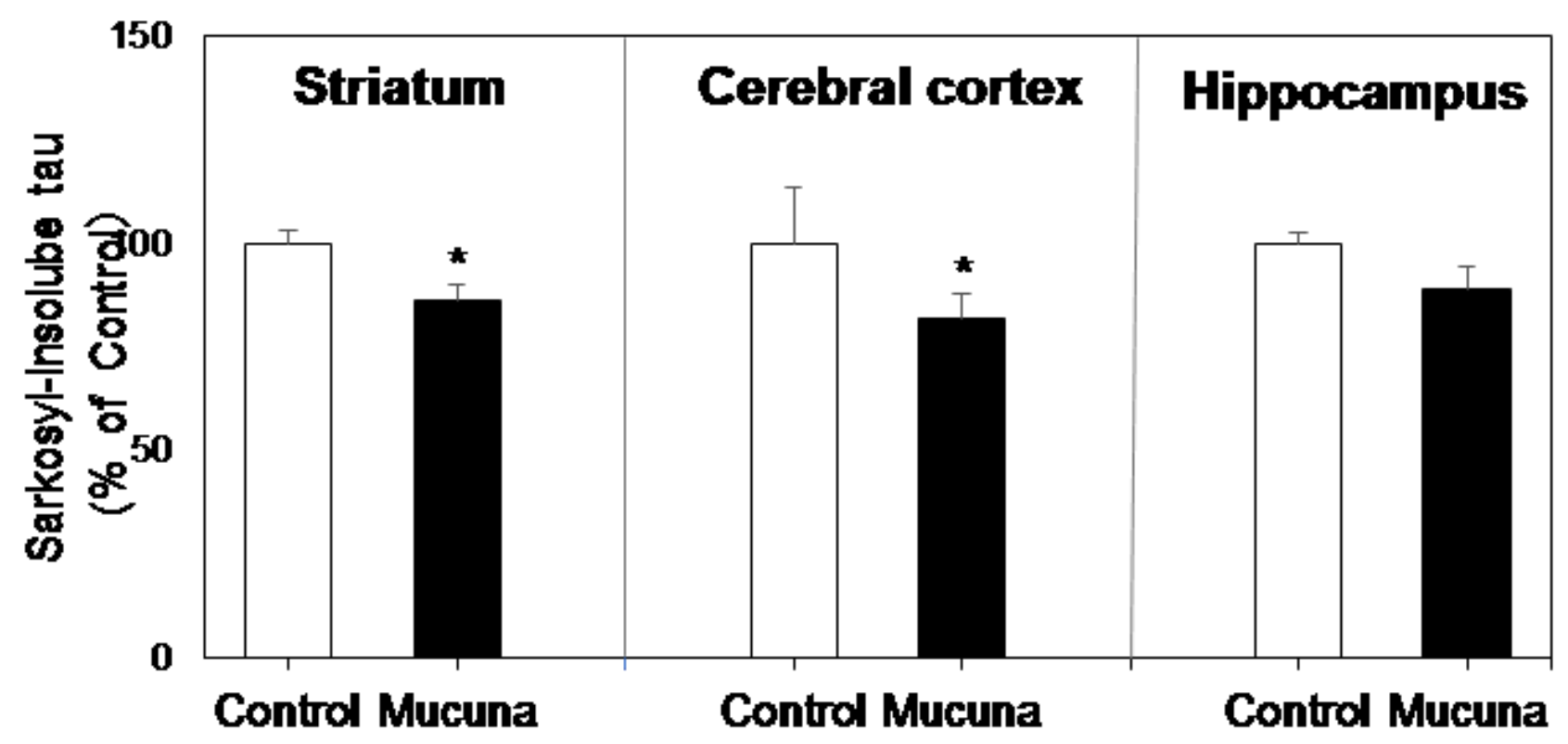

Figure 4.

Figure 4

Immunoblotting analysis of phosphorylated tau in the Sarkosyl-insoluble fraction. Sarkosyl-insoluble fractions were obtained from the striatum, cerebral cortex, and hippocampus homogenates of $3 \times T g-A D$ mice fed with the Mucuna diet (Mucuna group) or the Control diet (Control group). Levels of phosphorylated tau in the Sarkosyl-insoluble fraction were analyzed by immunoblotting using AT8 antibodies. Densitometry of phosphorylated tau immunoreactivity was quantified. Results are shown as percentage of Control values (means \pm SEM). Striatum: Control $n=7$, Mucuna $n=6$, Cerebral cortex: Control $n=7$, Mucuna $n=6$, Hippocampus: Control $n=6$, Mucuna $n=5 .<0.05$ versus Control by Student's t-test. 


\section{A: Control}

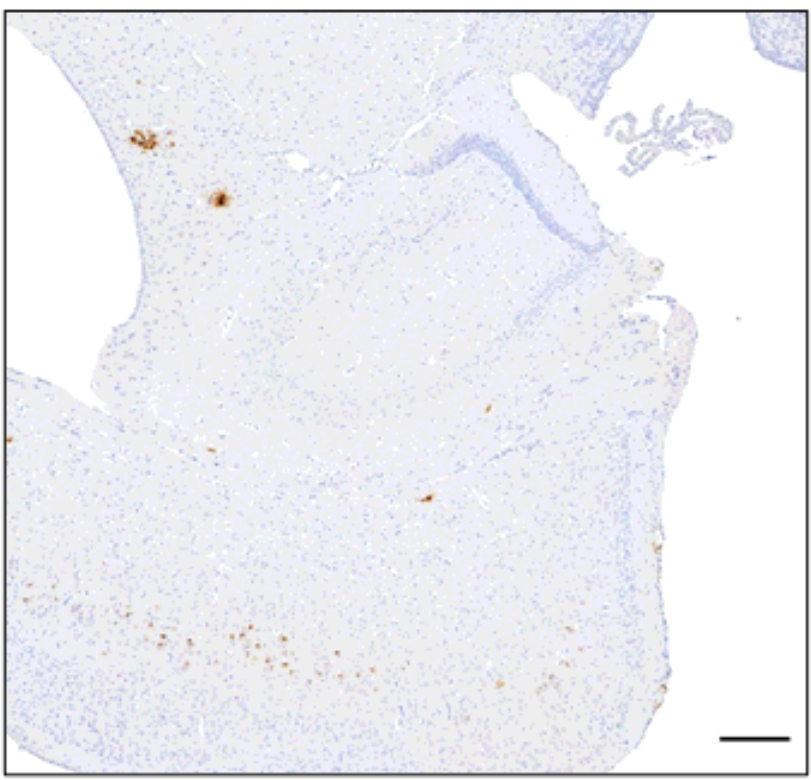

B: Mucuna

C

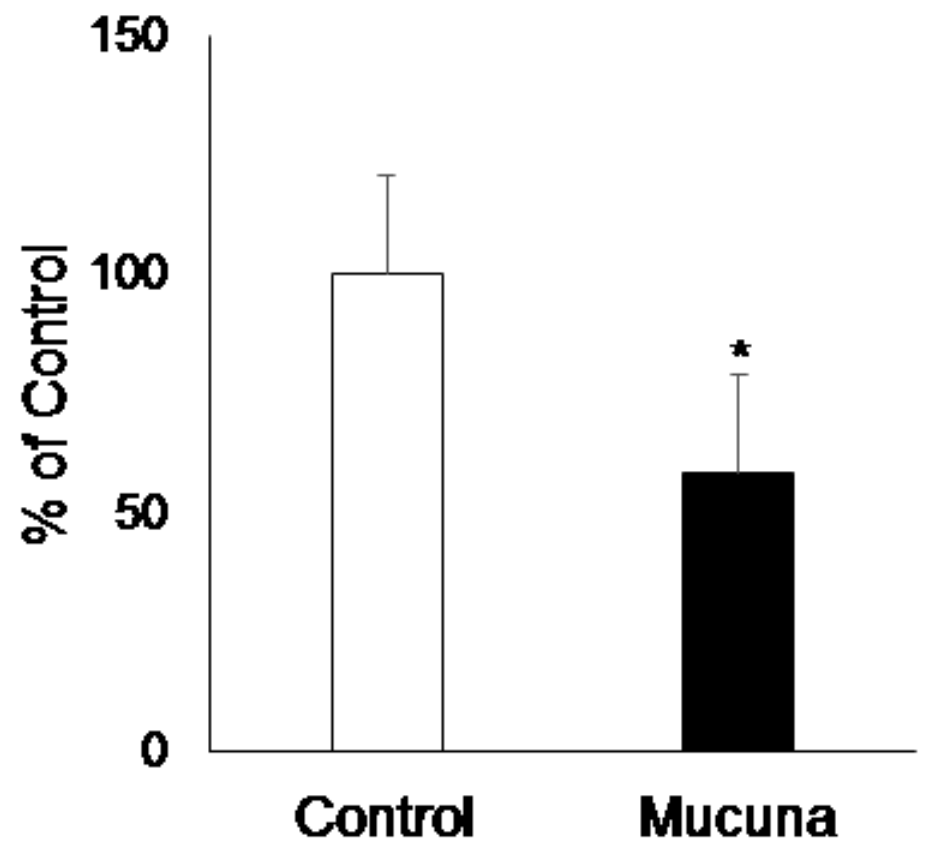

Figure 5.

Figure 5

$A \beta$ accumulation in the brain. $A, B$ : Representative images of the $6 E 10$-positive $A \beta$ accumulation immunostained with $6 \mathrm{E} 10$ in brain sections. (A) Control group. (B) Mucuna group. The scale bar represents $10 \mu \mathrm{m}$. (C) Quantification of the 6E10-positive $A \beta$ area in the brain. Results are shown as percentage of Control values (means \pm SEM, $n=6$ ). ${ }^{*} p<0.05$ versus Control by Student's t-test. 


\section{A: Control}

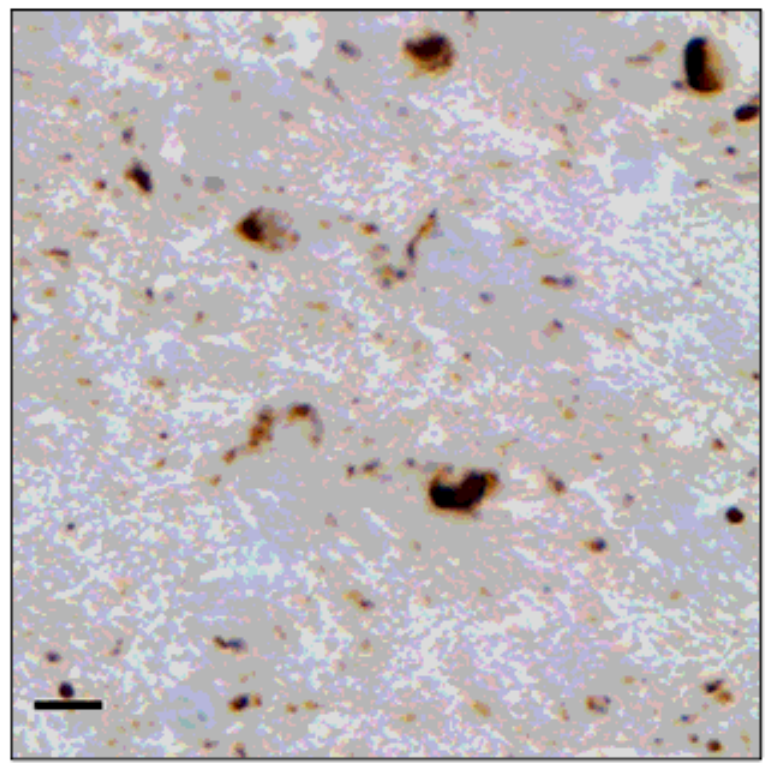

\section{B: Mucuna}

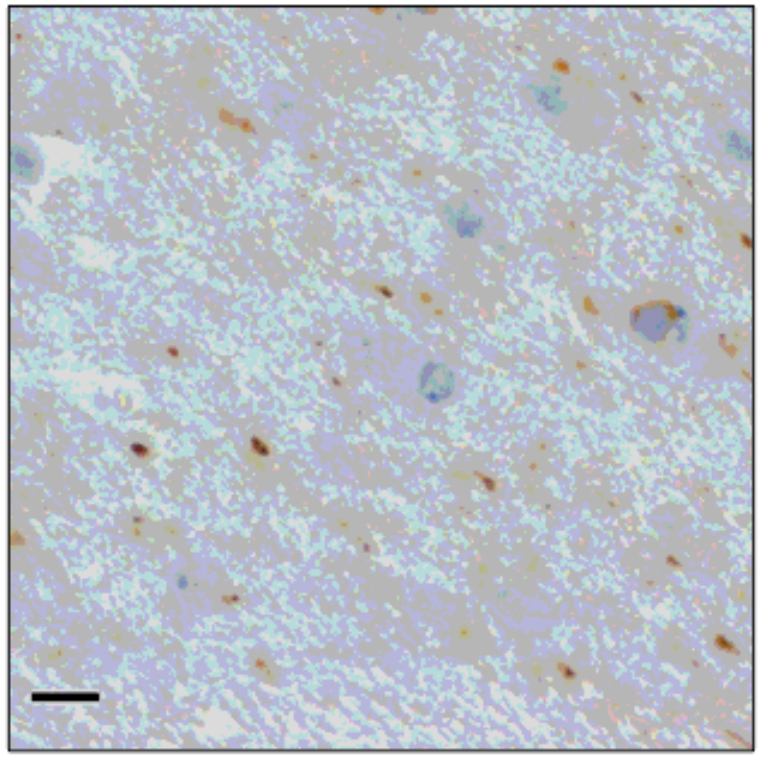

C

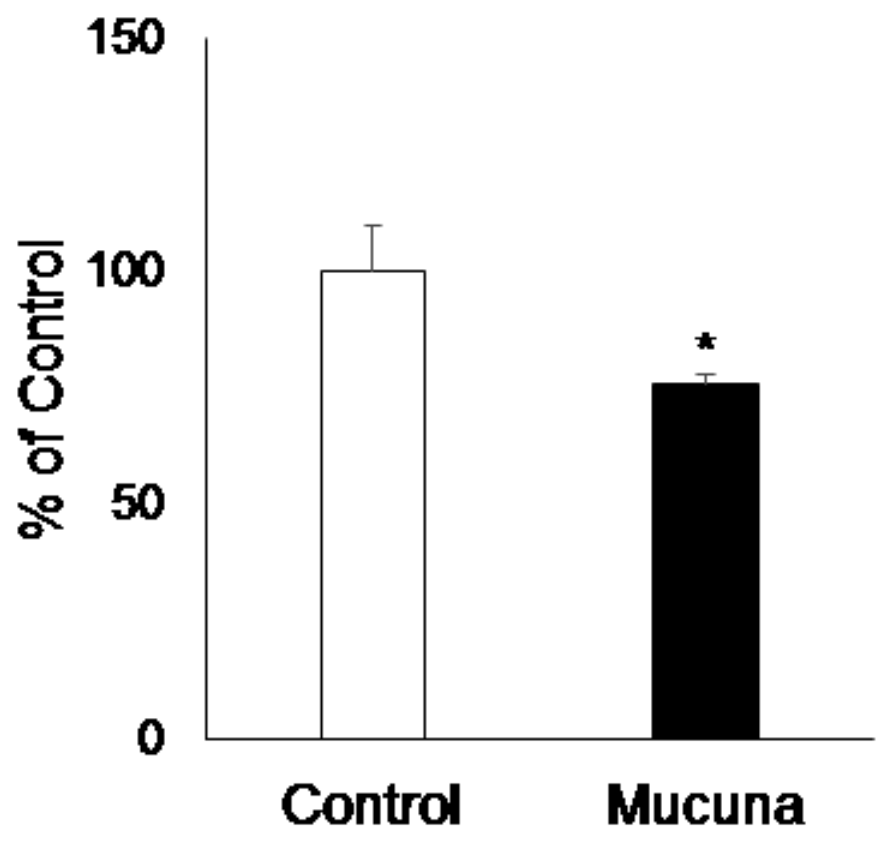

Figure 6.

Figure 6

Tau accumulation in the brain. A, B; Representative images of the AT8-positive tau accumulation immunostained with AT8 antibodies. (A) Control group. (B) Mucuna group. The scale bar represents 10 $\mu \mathrm{m}$. (C) Quantification of the AT8-positive tau area in the brain. ${ }^{\star} \mathrm{p}<0.05$ versus Control by Student's ttest. Values represent means $\pm S E M, n=6$. 


\section{Number of entries}

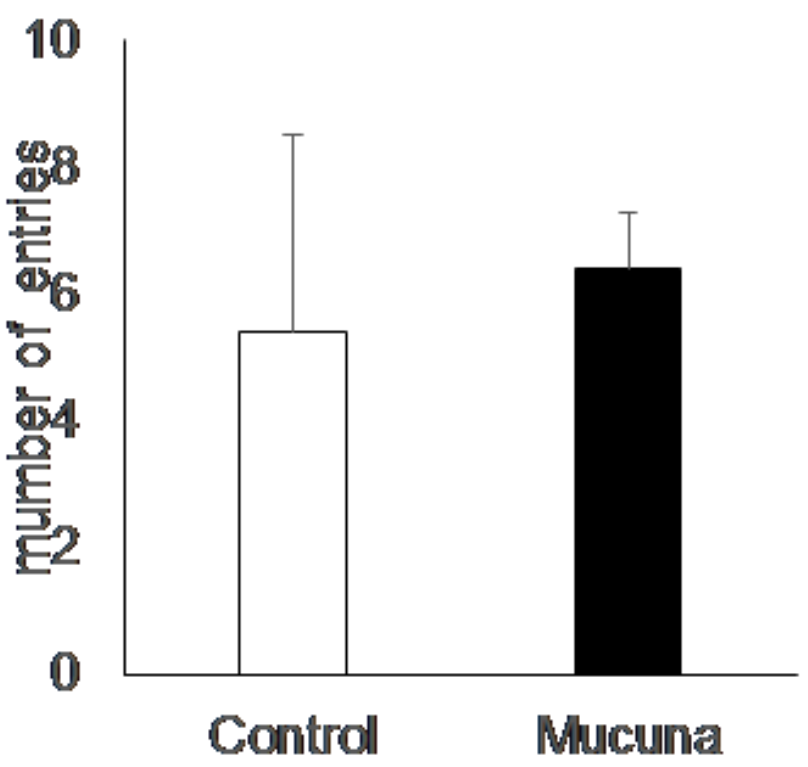

Percentage of alteration

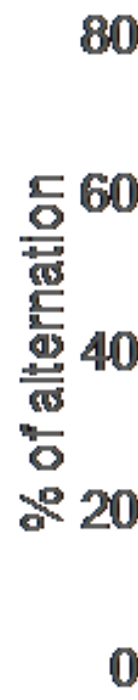

0

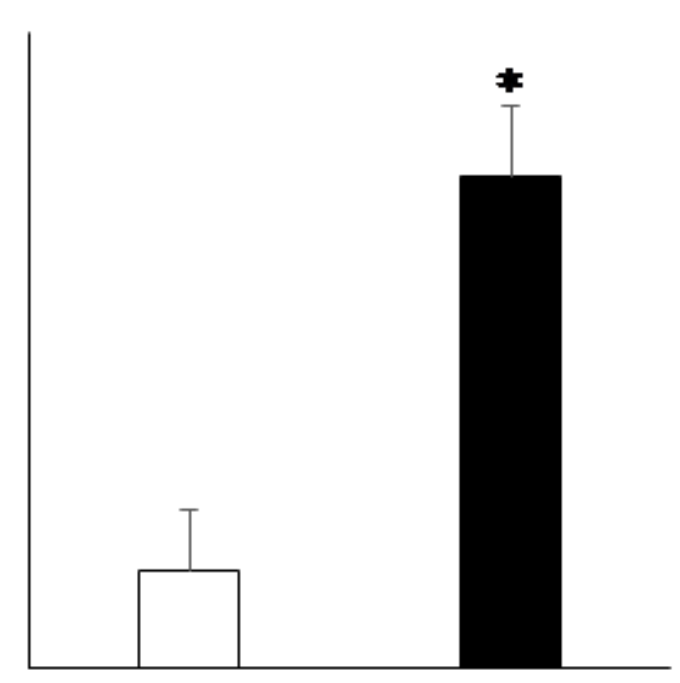

Controll
Muccuna

Figure 7.

Figure 7

$\mathrm{Y}$-maze performance in Mucuna-treated mice. The mice were tested with the $\mathrm{Y}$-maze paradigm for the number of entries and the percentage of alteration. Values represent means $\pm S E M, n=6 .{ }^{*} p<0.05$ versus Control by Student's t-test.

\section{Supplementary Files}

This is a list of supplementary files associated with this preprint. Click to download.

- Supportinginformationmaterials.docx

- supplementarydatasets1StriatumABblots.xIsx

- supplementarydatasets2CerebralcortexABblots.xlsx

- supplementarydatasets3HippocampusABblots.xlsx

- SupplementaryDataset4Striatumphosphorylatedtaublots.xlsx

- SupplementaryDataset5Cerebralcortexphosphorylatedtaublots.xIsx

- SupplementaryDataset6Hippocampusphosphorylatedtaublots.xlsx 